Review

\title{
Reviews of Geospatial Information Technology and Collaborative Data Delivery for Disaster Risk Management
}

\section{Hiroyuki Miyazaki ${ }^{1, *}$, Masahiko Nagai ${ }^{2,3, \dagger}$ and Ryosuke Shibasaki ${ }^{3, \uparrow}$}

1 Earth Observation Data Integration and Fusion Research Initiative, University of Tokyo, 4-6-1 Komaba Meguro, Tokyo 153-8505, Japan

2 Asian Institute of Technology, P.O. Box 4, Klong Luang, Pathumthani 12120, Thailand; E-Mail: nagaim@ait.ac.th

3 Center for Spatial Information Science, University of Tokyo, 4-6-1 Komaba Meguro, Tokyo 153-8505, Japan; E-Mail: shiba@csis.u-tokyo.ac.jp

$\dagger$ These authors contributed equally to this work.

* Author to whom correspondence should be addressed; E-Mail: heromiya@csis.u-tokyo.ac.jp; Tel.: +81-3-5452-6415; Fax: +81-3-5452-6412.

Academic Editors: Christoph Aubrecht and Wolfgang Kainz

Received: 22 June 2015 / Accepted: 18 September 2015 / Published: 29 September 2015

Abstract: Due to the fact that geospatial information technology is considered necessary for disaster risk management (DRM), the need for more effective collaborations between providers and end users in data delivery is increasing. This paper reviews the following: (i) schemes of disaster risk management and collaborative data operation in DRM; (ii) geospatial information technology in terms of applications to the schemes reviewed; and (iii) ongoing practices of collaborative data delivery with the schemes reviewed. This paper concludes by discussing the future of collaborative data delivery and the progress of the technologies.

Keywords: disaster risk management; geospatial information technology; data delivery; earth observation; ground-based observation; crowdsourcing; mobile phone 


\section{Introduction}

The issue of disaster risk management (DRM) is a priority for sustainable development [1]. Geospatial information technologies, such as geographic information systems (GIS), satellite remote sensing, and crowdsourcing, are important DRM technologies [2]. Following the increased awareness of geospatial information technology in DRM, international collaborative mechanisms of geospatial data delivery were established by international initiatives, such as the International Charter [3], Sentinel Asia [4], and Humanitarian OpenStreetMap Team [5]. These initiatives contributed to the damage assessment required in emergency response. However, because general investment in pre-disaster activities is expected to be more beneficial than spending for disaster response [6,7], geospatial information technology could contribute to pre-disaster activities for disaster risk management. Reviews of geospatial information technologies and how they can be applied in pre- and post-disaster situations will help identify schemes that are more effective.

In this paper, we reviewed (i) the schemes of disaster risk management and collaborative data operation in DRM; (ii) geospatial information technology in terms of its applications to the schemes reviewed; and (iii) the ongoing practices of collaborative data delivery for the schemes reviewed. We concluded with future perspectives of collaborative data delivery and the progress of technologies.

\section{Data Delivery Schemes for Disaster Risk Management}

\subsection{Temporal Considerations}

Although DRM is featured more in post-disaster situations, pre-disaster activities are important for reducing the impacts of disasters [8]. The US Government created a scheme for DRM, Comprehensive Emergency Management (CEM) [9], which suggests that governors coordinate pre- and post-disaster mitigation, preparedness, response, and recovery. This scheme is often referred to in DRM literature and suggested actions include the following:

- Mitigation - Long-term activities that actually eliminate or reduce disaster risks.

- Preparedness-Necessary actions for developing emergency response plans such that governments, organizations, and individuals can reduce disaster damage.

- Response-Post-disaster actions to provide emergency assistance and reduce secondary damages.

- Recovery-Activities that follow Response and continue until all systems return to normal (or better), including short-term activities for recovering vital life-support systems and long-term activities conducted for several years after a disaster.

In addition, Risk Assessment should be conducted first to identify risks and determine if the risks are acceptable or unavoidable [8]. For example, although the risk of traffic accidents is quite high, it is accepted by people because of the benefits of driving or because people have no other choice. In addition, some poor people cannot live in safe areas because of financial problems. Thus, whether such a risk is accepted or unavoidable should be managed with a good balance between risk and benefit [10]. 
Donahue [11] analyzed the budgeting framework of disaster risk management at the national, state and local levels in terms of functional competency, behavioral incentives, and policy in emergency management. The result suggested that current budgeting systems would likely promote response and recovery rather than mitigation and preparedness; however, the total cost of response and recovery for a disaster would be higher than of the cost of continuous mitigation and preparedness activities.

\subsection{Reference Model}

The Committee on Earth Observation Satellites (CEOS) developed a reference model for using satellites, sensors, models, and associated data products to support DRM within the Global Earth Observation System of Systems (GEOSS) [12]. The CEOS applied the ISO/IEC Reference Model of Open Distributed Processing (RM-ODP) to structure descriptions of DRM operations. RM-ODP is helpful for structuring the descriptions of an enterprise according to the following five viewpoints: the enterprise viewpoint, which describes the purpose, scope, and policy; the information viewpoint, which handles the semantics of information and information processing; the computation viewpoint, which describes the functional decomposition of the system and models the interaction of objects at interfaces; the engineering viewpoint, which describes the mechanism and functions required for distributed interactions between objects; and the technology viewpoint, which indicates technology choices for the system.

In the enterprise viewpoint, the CEOS describes the business processes of data delivery for DRM using the following series of phases: disaster warning, disaster response, disaster recovery, and disaster mitigation. Furthermore, the CEOS simplified business processes into three activities (initiation, event detection and response, and recovery and mitigation), and classified stakeholders as initiators, actuators, processors, and coordinators. For the information viewpoint, the CEOS clarified the needs of metadata, which helped identify the data necessary for urgent decision making and the satellite data processing operations needed by the end users. For the computation viewpoint, the data system should consider services for end users, such as catalog services, visualization, data access and ordering.

The CEOS concluded with perspectives for the engineering and technology viewpoints and highlighted the considerations of catalog service, data access, and interoperability among services and platforms. The developed reference model could serve as a guideline for delivering earth observation data in emergencies and is applicable to geospatial data products.

\section{Geospatial Information Technology for Disaster Risk Management}

\subsection{Analysis Scheme of the Reviews}

We reviewed the following geospatial information technologies in terms of their application to DRM for each of the phases mentioned above: earth observation, ground networks, crowdsourcing as a monitoring measure, and WebGIS and mobile phones as the end user interface. Combinations of technology are an important issue in the development of practical applications for DRM. In the following sections, we review geospatial information technologies and relevant practices in terms of their applicability at each phase of DRM. 


\subsection{Earth Observation}

Earth observations (EO) have served as an important information resource in DRM and has been applied to earthquakes [13-15], tsunami arrival predictions [16], volcanic hazards [17,18], floods [19-23], landslides [24,25], forest fires [26], and drought monitoring and prediction [27-31]. Earth observations can help to simultaneously capture the land condition of a broad area and are less expensive than field surveys. Although this feature is useful for any phase of DRM, it is especially useful for planning purposes. Although satellite remote sensing can be used to observe physical characteristics of the land surface, several studies have developed socioeconomic datasets relevant to vulnerability assessment, such as urban expansion [32,33], population [34], and gross domestic product (GDP) [35,36], by using a combination of satellite-based data and socioeconomic statistics.

Due to the risk assessment phases are less urgent, data providers and users can carefully prepare and choose sources and products in terms of scientific quality. Various EO-based data products of natural hazards are publicly available on the Internet. As suggested by the CEOS's reference model, catalog service for better data access and interoperability supports the choice of data. For example, the GEOSS Portal [37] and the Data Integration and Analysis System [38] provide user interfaces for searching datasets from the metadata provided by the data provider. Since risk assessment requires data on hazards and on the vulnerability to the hazard (e.g., exposed population, number of elderly people and children) [39-41], the data should be provided in a format that is interoperable with other data, such as the commonly used GIS formats.

In the mitigation phases, EO-based data are used for mitigation planning, such as land use zoning, based on the risk assessment results [40]. For example, for climate change mitigation and adaptation, which involve a large-scale policy implementation, EO data are used for long-term monitoring and for modeling the interactions between climate and human activity according to historical archives [42-44]. Therefore, such data support the efficiency of the plan-do-check cycle during the implementation of mitigation policies. For the preparedness phases, establishing an early warning system is the most recognized application of EO. Applications for early flood and drought warnings were proposed [20,21,27-29] and have been introduced as pilot operations [45].

For the response phases, two noteworthy features of EO are its high observation frequency and its rapidness of observations. Since the repeat intervals of most satellites are daily to monthly [46], it is feasible to acquire pre- and post-disaster satellite images that are helpful for quickly identifying damages. In addition, the Terra/ASTER [47], ALOS [48], ALOS-2 [49], and Sentinel-1 [50] satellites can respond to urgent requests for observations from emergency response teams. Moreover, although observation frequency could be a trade-off to spatial resolution, constellation satellites, such as RapidEye [51], COSMO-SkyMed [52], Pléiades system [53], and Sentinel system [50], breaks through the trade-off by using temporally-shifted satellites with identical specifications in the coplanar orbits [54]. Since changes in detection between pre- and post-disaster are the most effective and efficient methods for identifying hazard damages from satellite imagery [55,56], there is a potential need for baseline satellite images that cover disaster-prone areas, which can enable better preparedness. 
Due to the fact that recovery progress mostly appears on a very fine scale (e.g., removal of debris and the reconstruction of buildings) in the recovery phases, high-resolution satellite images are needed to identify changes for recovery [57,58]. If high-resolution satellite imagery is not affordable, technologies for crowdsourcing, which are mentioned below, could complement spatially-detailed information and data to monitor the recovery progress.

\subsection{Ground-Based Observation Networks}

Weather stations are commonly used for science, DRM, and in people's daily lives. Thus, weather stations are reliable data resources on the ground. Weather stations are mainly operated by national governments, and the US National Oceanic and Atmospheric Administration (NOAA) provides an Integrated Surface Database [59], which consists of hourly observations from numerous sources, and the Global Surface Summary of the Day [60], which provides daily global summaries of weather data that are exchanged under the World Meteorological Organization (WMO) World Weather Watch Program. Since the databases are not updated in real-time, they are used for scientific purposes rather than for operational use; however, they are also applied for drought monitoring [61,62].

NOAA's Meteorological Assimilation Data Ingest System (MADIS) provides real-time data from US-based weather stations and volunteer-based stations of the Citizen Weather Observer Program (CWOP), a volunteer-based weather observation program [63]. MADIS provides a developer-friendly public API to allow access to the data. WeatherUnderground [64] is a commercial service based on MADIS's API. Since CWOP contributes to real-time weather monitoring, the crowdsourcing of weather information provides value to social benefits [65] and the DRM.

The ground network of Global Navigation Satellite System (GNSS) base stations is also important for DRM. Positioning data from such networks were originally used for Real-Time Kinematic (RTK) GPS for better precision. For DRM purposes, high-rate GPS positioning at base stations can help model seismic dynamics [66-68]. A combination of the technique with interferometric SAR (InSAR) is effective for extending sparsely distributed observations to surface extents $[14,15]$. The real-time detection of epicenters can help predict the arrival of tsunamis in coastal areas [16]. The Continuously Operating Reference Station (CORS) network is a network of GNSS stations in the US that is operated by NOAA [69]. For international use, the International GNSS Service (IGS) provides access to tracking data from over 400 worldwide reference stations [70]. GPS buoys with high-rate positioning support offshore monitoring of tsunami and storm surges based on sea level [16,71-73]. With the support of communication satellites, buoys can achieve real-time forecasting of tsunami arrival. One advantage of buoys over coastal measuring instruments is their robustness against tsunamis [71].

One important note of using a ground network is that the communication infrastructure could be destroyed by disaster, as shown by the review of the 2011 East Japan Great Earthquake [74]. Backup communication systems, such as communication satellites [74] and movable communications systems [75], are necessary for disaster response operations. 
For the risk assessment phase of DRM, data from ground-based observation networks have the advantage of continuity but are spatially dispersed, in contrast with EO satellites. Therefore, ground-based observation networks complement EO satellites in observation frequency, as shown in seismic monitoring applications [14,15]. For preparedness phases, ground-based observation networks can be applied to early warning systems, as shown in the example of tsunami warning. The networks should involve the installation of technology and administrative arrangements and feasibility tests through evacuation drills that represent emergencies.

In the response phases, ground networks are used to monitor secondary hazards following primary hazards, such as tsunamis following large earthquakes [72]. Ground networks can be damaged by hazards. Therefore, it is safer to include the collaborative use of EO in the response plan.

\subsection{Crowdsourcing}

Due to the fact that user-driven content on the Internet has become popular, interactions between service providers and end users have occurred in the field of geospatial information technology. Crowdsourcing is an emerging method for collecting data and information from non-experts over the Internet. Although the scientific quality of crowdsourced data remains under discussion [76,77], crowdsourced data are helpful for efficient communication between people and public authorities. The applications of Ushahidi [78] and Sahana [79], which are open source software platforms for crowdsourcing GIS, were highlighted in response to the 2010 Haiti Earthquake and the 2011 Great East Japan Earthquake [80,81].

OpenStreetMap (OSM) is an outstanding volunteer-based activity of geospatial data development that uses GPS tracking and digitizing of high-resolution satellite/aerial imageries to create freely available global geographic data. OSM is considered a geospatial data platform because of its high performance in handling a large amount of geospatial data [82]. OSM provides a crowdsourcing platform for developing geospatial data by volunteers. Because the data are free for any purpose through the Open Database License (ODbL) [83], end users can use OSM's data without any payment or limitations. In addition, the Humanitarian OpenStreetMap Team (as discussed below) initiates mapping campaigns in emergencies if map data are not available in the disaster-afflicted areas.

Mobile phones are also useful for data collection in DRM. For example, people can send out local observations to public authorities, such as the observed damages from a hazard. FrontlineSMS is a comprehensive SMS management suite that collects posts from people, disseminates information to people, and has been applied to DRM and other social benefits [84,85]. Although FrontlineSMS originally did not have GIS support, Ushahidi provided georeferencing functions for SMS in combination with FrontlineSMS [86]. As smartphones further penetrated the market [87], the applications of mobile phones were extended to the use of multimedia, such as photos and videos and geotagging functions, by embedding GPS.

GPS-enabled smartphones and every SMS-enabled mobile phone can be georeferenced using Open GeoSMS by using the protocol standardized by the Open Geospatial Consortium [88]. Open GeoSMS is a protocol that is used to embed georeferenced information in SMS so that GIS software automatically recognizes SMS as georeferenced information. Georeferenced messages include messages such as "I'm at the Univ. Tokyo geo: $35.66,139.67 ; \mathrm{u}=100$ ”, indicates a location at a latitude of 35.66 and longitude 
of 139.67 with an uncertainty of 100 meters. Since Ushahidi and Sahana are compatible with GeoSMS, the software will help efficiently organize information posted from peoples' mobile phones.

Crowdsourcing has the advantage in understanding the needs based on the "people's voice", especially when using SMS [89]. Applying crowdsourcing could be helpful in the response and recovery phase, where governments should understand why people are suffering. Thus, SMS-based crowdsourcing can contribute to bridging the digital divide between Internet users and non-Internet users. In addition, based on the Internet, crowdsourcing platforms provide remote assistance opportunities worldwide. For example, anyone around the world can contribute to the development of geospatial data through OSM, which can contribute to better preparedness in disaster-prone areas [90,91].

\subsection{People Mobility}

Population data is a basic necessity to assess human exposure analysis to hazards. While population data is organized by administrative unit or census district, spatially more detailed data is needed for better planning of disaster risk management $[41,92,93]$. For the needs, grid-based global population data, such as Gridded Population of the World [94], Landcan [95], and WorldPop [96], was developed by using existing census data and ancillary geospatial data, such as land cover maps, road network data, terrain data, and night-time light satellite images.

In addition to spatially-detailed population mapping, temporal variety of population distribution, or people mobility, has been regarded important for disaster risk management [97]. Several studies presented frameworks and practices of spatio-temporal population mapping by measuring people's movement between daytime and nighttime [34,97] and spatio-temporal patterns of commutes between home and work $[98,99]$. The frameworks are extensible to other data for better accuracy and broader regions.

Location data acquired from mobile positioning devices have a notable potential to improve spatio-temporal population mapping. For example, GPS devices have become affordable to more people, particularly because they are embedded in mobile phones. In some countries, every cell phone handset is required to function with location notifications for security purposes, such as E911 in the US. Therefore, it is possible to use countywide individual GPS logs to model mobility in disaster situations. For example, GPS logs can be used to model the behavior of people following large-scale disasters, such as the 2011 East Japan Great Earthquake [100].

Even without GPS, the use of Call Detail Records (CDRs), which are records of mobile phone activity (calling, SMS, and data communications), can be used to monitor behavior. Every CDR can be linked to the location of the cell tower that the activity used for communication. Since mobile phone operators store CDR for billing purposes, the data are a valuable information source for mobility. CDR-based mobility data can help develop an epidemiological model of communicable diseases [101], disaster management during floods [102], and behavior models of evacuation [103], which can help in preparedness, response, and recovery operations. Some operational pilots have been demonstrated in past disasters $[104,105]$. 
Due to location information being sensitive to privacy issues [106-108], data providers and users must handle mobility data carefully by using practices such as the anonymization of individual profiles. Some anonymization techniques were proposed with respect to handling spatial data [109].

Mobility data indicate the dynamics of the population on a detailed time scale; for example, the difference between day and night. Therefore, the data could serve as a valuable information source for disaster risk assessment in which the number of casualties should be estimated for a hazard. Furthermore, the data could be applied to behavior following hazards [100] to better plan mitigation and preparedness based on the behavior modeled by the mobility data.

\subsection{WebGIS}

The GIS helps decision-makers handle data and information with multiple criteria in DRM [110]. In past decades, technologies has been extended to the Internet or WebGIS such that non-GIS users can browse geospatial data from a data provider through user-friendly map interfaces on their computers or smartphones, even without intensive GIS training. WebGIS has played an important role in DRM for sharing the information and data required for decision-making among multiple agencies [111]. To improve the interoperability of geospatial data among agencies, standards for Internet-based geospatial data protocols have been developed by the Open Geospatial Consortium (OGC). These standards include the Web Map Service (WMS) [112] and the Web Feature Service (WFS) [113], which have promoted the interoperability of geospatial data and information because most major GIS software packages are compatible with these standards [114]. Based on the established standards, several data providers have published their data in the Internet-based format [115-117], which has enabled service developers to easily introduce their data into WebGIS. This style of service development combining various data sources is often called a "mashup" [118]. SEDAC Hazards Mapper [119] and DisasterAWARE [120] are practical applications for disaster response decision-making when combined with near-real time data from hazards and background socio-economic data.

WebGIS works as a communication tool among experts and non-experts [121] and helps non-experts understand the geospatial context in areas of their interests. These functions of WebGIS can be applied to understand risks to allow communities to better prepare and respond to them [122,123]. Workshops of scenario-based risk communication with the local community are effective for enhancing the local capacity for handling DRM information platforms [124].

Due to its role as an end user interface of geospatial information, WebGIS is useful for every phase of DRM. However, WebGIS only works if it is connected to the Internet. In the response phase, WebGIS could be useless if the communications infrastructure is damaged. In such cases, the "offline mode" of WebGIS is needed to maintain Internet-based data on local computers. With such an "offline mode", mobile devices such as laptop computers, tablets, and smartphones would be a good medium for delivering Internet-based geospatial data to the field when disconnected from the Internet. 


\subsection{Mobile Phones}

As mobile phones have become more affordable [125], they could be used to deliver information, such as early warnings, to people with little access to critical information. However, information delivery should be selective by location; otherwise, people far from afflicted areas could be confused by early warnings for the areas that are at risk. To improve trust in these early warnings and the quickness of decisions following alerts, several attempts have been made to disseminate location-based alerts via mobile phones [90].

Mobile phone SMS allows for the efficient dissemination of information, such as early alerts, by using alphabetical texts, which could be a barrier for non-alphabet languages. InSTEDD provides some SMS-based technologies in local languages based on easy-to-develop voice navigation systems and predefined reporting codes in SMS [126,127].

In addition to WebGIS, mobile phones are end user interfaces of DRM information and will work well for DRM in every phase. Unlike WebGIS, the form of data and information is limited to voices and texts, particularly for basic phones. In addition, the communications infrastructure could be damaged by hazards [74]. One advantage of mobile phones is their connectibility to people because nearly all adults have mobile phones with them at all times. Therefore, mobile phones provide a channel for delivering minimum but critical information. Thus, the most important application is the establishment of early warning systems in the preparedness phases.

\section{Practices of Collaborative Data Delivery for Disaster Risk Management}

In this section, we review the on-going practices of geospatial data delivery for DRM. We analyze the practices in term of the functions for each phase of DRM suggested in the sections above. Table 1 shows a list of geospatial data delivery activities, which are reviewed below. In this review, we focused on the activities that contributed to the delivery of geospatial information for DRM as technology providers. However, there are several international groups and initiatives working for DRM, including UNISDR [128], UNOOSA/UN-SPIDER [129], the AHA Centre [130], the Asian Disaster Preparedness Center [131], and the Asian Disaster Reduction Center [132], who would rather contribute to high-level coordination and knowledge management. 
Table 1. Activities of Geospatial Data Delivery for Disaster Risk Management.

\begin{tabular}{|c|c|c|c|c|c|}
\hline \multirow{2}{*}{ Organization/Initiative } & \multirow{2}{*}{ Technology } & \multicolumn{3}{|c|}{ Phases of Disaster Risk Management } & \multirow{2}{*}{ Data Delivery } \\
\hline & & Risk Assessment & Mitigation/Preparedness & Response/Recovery & \\
\hline Sentinel Asia & $\begin{array}{l}\text { Earth } \\
\text { observation }\end{array}$ & $\begin{array}{l}\text { Development of } \\
\text { hazard map from } \\
\text { EO data. }\end{array}$ & $\begin{array}{l}\text { - Development of early warning system. } \\
\text { - Capacity building of local communities. } \\
\text { - Capacity building on the Sentinel Asia System. }\end{array}$ & $\begin{array}{l}\text { - Providing EO data from the Data Provider Node. } \\
\text { - Provided EO data are analyzed using the Data Analysis } \\
\text { Node members for value-added products. }\end{array}$ & $\begin{array}{l}\text { - Raw EO data for authorized users. } \\
\text { - PDF, PNG, or JPEG maps are available on the website. } \\
\text { - Public WebGIS for browsing EO data and maps. }\end{array}$ \\
\hline International Charter & $\begin{array}{l}\text { Earth } \\
\text { observation }\end{array}$ & & & Providing EO data from member space agencies. & $\begin{array}{l}\text { - Raw EO data for authorized users. } \\
\text { - PDF, PNG, or JPEG maps are available on the website. } \\
\text { - Public WebGIS to browsing EO data. }\end{array}$ \\
\hline \multirow{4}{*}{ UNITAR/UNOSAT } & $\begin{array}{l}\text { Earth } \\
\text { observation }\end{array}$ & \multicolumn{2}{|c|}{$\begin{array}{l}\text { Capacity building with lectures and exercises of concepts and GIS } \\
\text { methodologies for performing satellite based analysis for emergency } \\
\text { response. }\end{array}$} & $\begin{array}{l}\text { - Support to UN and other activities for disaster response. } \\
\text { - Support to post-disaster needs assessment. }\end{array}$ & \multirow{4}{*}{$\begin{array}{l}\text { GIS vector format (ESRI Shapefile and File GeoDatabase) } \\
\text { and PDF map are publicly available on the website. }\end{array}$} \\
\hline & \multirow{3}{*}{$\begin{array}{l}\text { Crowd } \\
\text { sourcing }\end{array}$} & & & $\begin{array}{l}\text { Pilots on visual interpretation of satellite images for } \\
\text { damage assessment [133]. }\end{array}$ & \\
\hline & & & & - Collecting geo-tagged photos by smart phones [134]. & \\
\hline & & & & - Organizing situational information by photo tagging. & \\
\hline \multirow{2}{*}{ Copernicus EMS } & $\begin{array}{l}\text { Earth } \\
\text { observation }\end{array}$ & \multicolumn{3}{|c|}{$\begin{array}{l}\text { On-demand production of satellite-based maps and GIS data. The data and maps are delivered to end users within nine hours to five } \\
\text { days for emergency use and } 20 \text { days for non-emergency use. }\end{array}$} & $\begin{array}{l}\text { GIS vector format (ESRI Shapefile and Google Earth } \\
\text { KMZ), PDF, and JPEG maps are available on the website. }\end{array}$ \\
\hline & $\begin{array}{l}\text { Ground-based } \\
\text { observation }\end{array}$ & \multirow{2}{*}{\multicolumn{2}{|c|}{ Early warning (only for Europe). }} & & Archived information is browsable on the website. \\
\hline $\begin{array}{l}\text { USGS Emergency } \\
\text { Response }\end{array}$ & $\begin{array}{l}\text { Earth } \\
\text { observation }\end{array}$ & & & $\begin{array}{l}\text { - Acquisition of EO data. } \\
\text { - Managing EO data acquisition requests. }\end{array}$ & $\begin{array}{l}\text { - Raw EO data for public or for authorized users. } \\
\text { - WebGIS for browsing EO data. } \\
\text { - Web-based protocol (WMS and REST). }\end{array}$ \\
\hline $\begin{array}{l}\text { Humanitarian } \\
\text { OpenStreet Map }\end{array}$ & $\begin{array}{l}\text { Crowd } \\
\text { sourcing }\end{array}$ & \multicolumn{2}{|c|}{$\begin{array}{l}\text { Development of mapping communities for preparing baseline data and } \\
\text { DRM planning. }\end{array}$} & $\begin{array}{l}\text { - Activation of volunteers } \\
\text { - Collection and management of data sources. } \\
\text { - Task management. } \\
\text { - Mapping damaged buildings and infrastructures for } \\
\text { damage assessment. }\end{array}$ & $\begin{array}{l}\text { GIS vector data and rendered map images are publicly } \\
\text { available from OSM and third parties on the Internet. }\end{array}$ \\
\hline
\end{tabular}


Table 1. Cont.

\begin{tabular}{|c|c|c|c|c|c|}
\hline \multirow{2}{*}{ Organization/Initiative } & \multirow{2}{*}{ Technology } & \multicolumn{3}{|c|}{ Phases of Disaster Risk Management } & \multirow{2}{*}{ Data Delivery } \\
\hline & & Risk Assessment & Mitigation/Preparedness & Response/Recovery & \\
\hline SERVIR & $\begin{array}{l}\text { Earth } \\
\text { observation }\end{array}$ & \multicolumn{2}{|c|}{$\begin{array}{l}\text { Development of applications and tools using EO } \\
\text { data for decision making. }\end{array}$} & Imagery taken from the International Space Station (ISS). & $\begin{array}{l}\text { - The applications are searchable on the website. } \\
\text { - ISS imagery is available to the public. }\end{array}$ \\
\hline \multirow{2}{*}{$\begin{array}{l}\text { Famine Early } \\
\text { Warnings Network }\end{array}$} & $\begin{array}{l}\text { Earth } \\
\text { observation }\end{array}$ & \multirow{2}{*}{$\begin{array}{l}\text { Monitoring and } \\
\text { forecasting food } \\
\text { security status. }\end{array}$} & \multirow{2}{*}{$\begin{array}{l}\text { Early warning with the Integrated Food Security } \\
\text { Phase Classification. }\end{array}$} & & \multirow{2}{*}{$\begin{array}{l}\text { Data in GeoTiff and maps in PDF and PNG are available } \\
\text { from the data portal website. }\end{array}$} \\
\hline & $\begin{array}{l}\text { Ground-based } \\
\text { observation }\end{array}$ & & & & \\
\hline \multirow{2}{*}{ Pacific Disaster Center } & $\begin{array}{l}\text { Earth } \\
\text { observation }\end{array}$ & \multirow{2}{*}{\multicolumn{2}{|c|}{$\begin{array}{l}\text { - Exercises and capacity building with the DisasterAWARE platform, } \\
\text { which integrates various DRM information. } \\
\text { - Support in risk assessment. } \\
\text { - Data modeling and visualization. }\end{array}$}} & Support in providing near real-time data from & 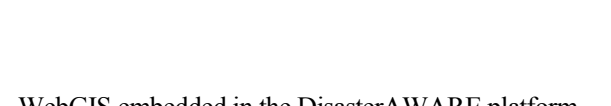 \\
\hline & $\begin{array}{l}\text { Ground-based } \\
\text { observation }\end{array}$ & & & EMOPS platform. & 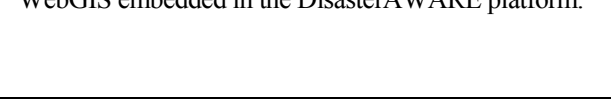 \\
\hline GEO GSNL & $\begin{array}{l}\text { Earth } \\
\text { observation }\end{array}$ & $\begin{array}{l}\text { Monitoring } \\
\text { seismic activities. }\end{array}$ & & $\begin{array}{l}\text { Initiating event supersites of areas affected by } \\
\text { large-scale hazards. }\end{array}$ & $\begin{array}{l}\text { Data are available at the website or by contacting data } \\
\text { authors. }\end{array}$ \\
\hline \multirow{3}{*}{$\begin{array}{l}\text { Global Disaster Alert } \\
\text { and Coordination } \\
\text { System }\end{array}$} & $\begin{array}{l}\text { Earth } \\
\text { observation }\end{array}$ & \multirow{2}{*}{\multicolumn{2}{|c|}{$\begin{array}{l}\text { - Providing early alerts of major disasters. } \\
\text { - Operation of the Global Flood } \\
\text { Detection System. }\end{array}$}} & \multirow[b]{2}{*}{ Impact estimation and assessment after major disasters. } & \multirow{2}{*}{$\begin{array}{l}\text { - Disaster alerts on maps at the website. } \\
\text { - Disaster event feeds in RSS, KML, and CAP } \\
\text { - Compilation of geospatial data by event. }\end{array}$} \\
\hline & $\begin{array}{l}\text { Ground-based } \\
\text { observation }\end{array}$ & & & & \\
\hline & $\begin{array}{l}\text { Crowd } \\
\text { sourcing }\end{array}$ & & & Field information collection by social media. & \\
\hline
\end{tabular}




\subsection{Sentinel Asia}

The Sentinel Asia initiative is a collaboration between space agencies and disaster management agencies in which remote sensing and WebGIS technologies are applied to support disaster management activities in the Asia-Pacific region [4,135]. Sentinel Asia conducts emergency observations by using EO satellites for major disasters. Currently, the participating satellites include ALOS-2 (Japan Aerospace Exploration Agency, Japan), IRS (Indian Space Research Organization, India), THEOS (Geo-Informatics and Space Technology Development Agency, Thailand), KOMPSAT-1 (Korea Aerospace Research Institute, South Korea), FORMOSAT (National Applied Research Laboratories, Taiwan), and XSAT (Centre for Remote Imaging, Sensing and Processing, Singapore), which are referred to as the Data Provider Node (DPN). In contrast, the Data Analysis Node (DAN) is used for data analysis and includes DRM agencies, research institutes, universities, and international organizations. The DAN analyzes the satellite data provided by DPN to make a value-added product and to disseminate the product through the Sentinel Asia System within the domestic legislation. To create value-added products, data should include various DPN satellite data with the local GIS dataset and field reports from local collaborators. The products are organized in map form and are publicly available on the website.

Information integration for both scientific and socio-economic data is important for making value-added products. The validation of map products requires ground verification as soon as possible before product dissemination. In addition to providing data products, Sentinel Asia supports the development of the local capacity to analyze satellite data to tackle disaster response. In addition, Sentinel Asia intends to support and expand the regional DRM capacity because most developing countries do not have their own satellites and necessary facilities, such as satellite data receiving stations and early warning systems.

Sentinel Asia primarily focuses on the response phases and has gradually expanded its activity to cover the entire DRM cycle of pre-disaster monitoring, preparedness, and recovery, which is necessary for DRM agencies and local communities to reduce disaster risk in the region. Sentinel Asia also conducts specific case studies with regional partnerships that include end users.

\subsection{International Charter on Space and Major Disasters}

The International Charter on Space and Major Disasters, called the International Charter, is a worldwide collaboration among space agencies $[3,136]$, in contrast with Sentinel Asia, whose activities are for the Asian and Pacific regions. The currently participating agencies include the European Space Agency (ESA), French Space Agency (CNES), Canadian Space Agency (CSA), NOAA, National Commission for Space Activities of Argentina (CONAE), Indian Space Research Organization (ISRO), Japan Aerospace Exploration Agency (JAXA), US Geological Survey (USGS), DMC International Imaging (DMCii), China National Space Administration (CNSA), German Space Agency (DLR), Korea Aerospace Research Institute (KARI), National Institute For Space Research of Brazil (INPE), European Organization for the Exploitation of Meteorological Satellites (EUMETSAT), and Federal Space Agency of Russia (ROSCOSMOS). The International Charter aims to deliver satellite data from member agencies within two weeks following disaster occurrence. A value-adding agency interprets and analyzes 
the acquired satellite images for damage assessment. These maps delineate affected areas and other related features. The developed map products are usually publicly available on the website.

Sentinel Asia collaborates with the International Charter, which regionally enhance it because it allows any country in the region to join the Sentinel Asia network and request disaster-relevant information, regardless of their membership in the International Charter or their level of investment in space-related infrastructure.

\subsection{UNITAR Operational Satellite Applications Programme (UNOSAT)}

UNOSAT is a program by UNITAR that delivers geospatial data and information to relief and development organizations both inside and outside of the UN system to make a difference in critical areas [137]. UNOSAT develops solutions based on the needs of the beneficiaries at the end of the process and has partnerships with international organizations and private sectors of geospatial information providers, such as the Asian Disaster Preparedness Center (ADPC), Digital Globe, e-GEOS, Environmental Systems Research Institute (ESRI), ESA, European Space Imaging (ESI), Global Facility for Disaster Reduction and Recovery (GFDRR), Google, the International Charter, ITC, Kongsberg Satellite Services (KSAT), MFB-GeoConsulting, Spot Image, Trimble, and WMO. For disasters and other crises, UNOSAT develops geospatial data products, such as damage assessments and the locations of refugee camps, from EO data using collaborative mechanisms, such as crowdsourcing [133,134], and publishes the data in map and GIS data formats on their website.

UNOSAT is not only dedicated to technology research and development but also to the development of the local capacity of pre-disaster activities. In addition, UNOSAT helps communities retain this capacity by integrating training modules and programs, which typically include GIS, satellite remote sensing, and smart phone applications [134]. UNOSAT's capacity development includes practical training on geospatial information technology within various application domains, including DRM, water management, and territorial planning. UNOSAT provides programs for a wide range of one-day workshops and long-term capacity development programs, including workshops and information sharing, in-country capacity building programs, and basic, advanced, and master level courses.

Similar to Sentinel Asia and the International Charter, UNOSAT provides DRM-relevant data when disasters occur. Since their data deliveries are conducted soon after the occurrence of disasters, their data products contribute to disaster response. Furthermore, because UNOSAT closely collaborates with UN organizations in the field, such as the UN Office for the Coordination of Humanitarian Affairs (UNOCHA), they can see the immediate needs from the field.

In addition to the development and delivery of geospatial information data products, UNOSAT contributes to the better mitigation and preparedness of DRM by providing geospatial information technologies training to local governments and communities. Their training programs aim for better resilience through risk assessment, mitigation, and preparedness by local governments and communities in DRM [138,139]. 


\subsection{Copernicus Emergency Management Service}

Copernicus is a program that has been conducted by the ESA since 1998 and was originally initiated as GEMS (Global Monitoring for Environment and Security). Copernicus creates geospatial data for DRM pre- and post-disaster phases by using EO [140]. Although the EU member states are primarily authorized to request the service, public entities, international organizations, national organizations, and non-governmental organizations can coordinate with the EU member states to request the service. In addition, the dataset created by the service is publicly available on the web site in maps and GIS data formats. The created maps are archived and searchable by hazard event using the WebGIS on the website. The data are delivered to the end users within nine hours to five days for emergency uses, such as response and recovery and within 20 days for non-emergency uses, such as risk assessment, mitigation, and preparedness.

The service classifies the following product types: reference maps, which provide information of pre-disaster situations for territories, assets and other ground features; delineation maps, which provide information regarding the extent of areas with hazard impacts; grading maps, which provide information regarding asset and infrastructure damage caused by the hazard; pre-disaster situation maps, which indicate possible hazard exposure, vulnerability, and other risk information; and post-disaster situation maps, which indicate post-disaster needs assessment, recovery status and plans. Since the service is under operation by ESA, it primarily uses the data provided by ESA's observation instruments, such as the Sentinel missions [141], and EU-based instruments, such as COSMO-Skymed [142], for the thematic map products. In addition, the service uses data provided by space agencies and international initiatives.

Furthermore, the service provides early warnings for floods based on historic and real-time water discharge and level data across Europe [143]. The flood forecasts and warnings are disseminated through its partners in Europe and the WebGIS on the website.

\subsection{USGS Emergency Response}

The US Geological Survey operates a platform, the Emergency Response, for acquisition of EO data [144]. Users can browse and use the archived USGS EO data for DRM purposes through a WebGIS-based interface, the Hazards Data Distribution System (HDDS). Publicly available satellite data and data with limited access, such as commercial-based satellite data, are browsable on the WebGIS interface. The HDDS provides a dataset with multiband GeoTiffs, which are good for remote sensing analysis, and composite images via WMS and Representational State Transfer (REST) for some dataset. The HDDS provides pre- and post-disaster satellite data according to disaster event.

In addition, the platform can be used to request satellite data acquisition from its users through the WebGIS-based interface, the Collection Management Tool, which is integrated with HDDS for better data management efficiency on the platform.

\subsection{Humanitarian OpenStreetMap Team (HOT)}

HOT is a volunteer-based group that applies the principles of open source and open data sharing to humanitarian response and economic development [145]. Although their activities are based on OSM (as the name indicates), they are independent of OSM but closely collaborates with OSM. HOT activates 
OSM mappers for crisis response or "crisis mapping", not only for natural disasters but also for armed conflicts. They efficiently facilitate efforts among volunteers by providing a tasking function; the OSM Tasking Manager [5]. In addition, they conduct learning programs, such as the development of learning materials, meetings, and conferences, to involve international volunteers and local communities for mapping activities to achieve better quality geospatial data.

Their activities were proved in response to the Haiti Earthquake in 2010. Between 2009 and June 2015, their OSM mapping has been initiated for 39 events [146]. Their initiation of mapping to disaster response contributes to the geographic information of afflicted areas, even during the very early stage of disaster response; thus, their output maps are used in emergencies for more effective disaster response [5,147].

As indicated above, crowdsourcing can contribute to better DRM preparedness. HOT has a partnership with the World Bank to bring the advantages of open, community mapping projects to the challenges of building resilience to natural disasters and the impacts of climate change in Haiti, Indonesia, the Philippines, and Malawi [148]. In addition, HOT conducts a program in Indonesia for better preparedness [149].

\subsection{SERVIR}

SERVIR is a joint initiative of the National Aeronautics and Space Administration (NASA) and the United States Agency for International Development (USAID) for better utilization of earth observation technology in developmental decision making [150]. SERVIR has conducted projects in over 30 countries with themes of adaptation, agriculture, climate, disaster, biodiversity, health, sustainable landscapes, water, and weather. In addition, they conduct projects through close collaborations with regional agencies, such as the Regional Centre for Mapping of Resources for Development (RCMRD), an intergovernmental organization that aims to promote the generation, application and dissemination of geospatial information for development issues in the Eastern and Southern Africa Regions.

As this initiative focuses more on application development, such as hydrology modeling and forest fire detection using EO data resources, it does not provide many EO data resources. However, although it provides fewer satellite resources than other activities, it does provide images taken from the International Space Station (ISS) with a camera, the ISS SERVIR Environmental Research and Visualization System (ISERV) [151,152]. ISERV takes images for disaster response and recovery requests, many of which are available to the International Charter.

\subsection{Famine Early Warning Systems Network (FEWS NET)}

The FEWS NET is an organization established by USAID in 1985 that provides evidence-based analysis of food security to help decision-makers and relief agencies in Central America, the Caribbean, Central Asia, East Africa, Southern Africa, and West Africa [153]. The FEWS NET monitors agricultural markets, agroclimatology, livelihoods, and nutrition through collaborations with science agencies, governments, international organizations, and NGOs and provides regular reports to stakeholders. Integrated Food Security Phase Classification, which is a widely accepted standard for describing food security status, is applied for the early warning of food crises forecasted by the analysis. 
Earth observation and ground-based observation are applied to their analysis, especially for monitoring agroclimatology conditions such as rainfall, soil moisture, vegetation conditions, and evapotranspiration. The developed dataset has been kept operationally up-to-date and freely available at the Data Portal website [30]. In addition, the dataset serves as a basis for scientific research regarding the agricultural issue of food security [154,155].

\subsection{Pacific Disaster Center (PDC)}

Pacific Disaster Center (PDC) is an organization that provides science and technology for DRM. The PDC was established after Hurricane Iniki, which struck Hawaii and devastated the island of Kauai in 1992 [156,157], and is currently managed by the University of Hawaii. The PDC provides decision support applications with user-friendly interfaces on web browsers and smart phones by using geospatial information of hazards and vulnerability provided from other DRM agencies. DisasterAWARE is a platform solution that can be used to organize real-time information from various agencies around the world on a map-based interface with background socioeconomic information, historical hazard records, and end user's data. Emergency Operations (EMOPS) supports sharing situational information posted by authorized users among stakeholders in emergencies and can be used to map news, traffic cameras, and social media.

In addition, the PDC conducts support for introducing technologies with capacity development programs, which are applicable to every phase of DRM. For example, custom versions of DisasterAWARE have been deployed to national and international agencies with exercise support and training.

\subsection{GEO Geohazards Supersites and Natural Laboratories (GSNL)}

GEO Geohazards Supersites and Natural Laboratories (GSNL) is an initiative of the geohazard scientific community that is supported by the Group on Earth Observations, the intergovernmental partnership creating a Global Earth Observation System of Systems (GEOSS) that will link earth observation resources world-wide across social benefits [158]. This initiative was established to promote international efforts to monitor and study selected cites with open access to relevant datasets [159]. In addition, this initiative was setup at additional supersites where large-scale geohazard events, such as the 2015 Nepal earthquake, have occurred.

Since the initiative's main targets are earthquakes and volcanoes, the provided datasets, such as the outputs of InSAR, the analysis output of continuous GNSS records, and their input data, are mainly for monitoring seismic activities. As the initiative is for scientific purposes, the distribution of the dataset is not completely free and the process is not standardized among the selected sites. However, the data archives are intensive; thus, the data archive would be useful for pre-disaster activities with a certain expertise in handling such scientific data products.

\subsection{Global Disaster Alert and Coordination System (GDACS)}

The Global Disaster Alert and Coordination System (GDACS) is a cooperation framework between the United Nations, the European Commission and disaster managers from around the world and is aimed at improving alerts, information exchange and coordination during the first phase of 
disasters [160]. The GDACS publicly provides early alerts for disasters by sourcing operational satellite monitoring and ground-based observations. The early alerts are retrievable as maps on the website, and in computer-readable structured formats (RSS and KML), which enables third parties to easily use the data for their own applications. Smart phone applications are also available from the website and provide impact estimations and assessments after major disasters for response and recovery phases.

The GDACS experimentally operates the Global Flood Detection System with the Dartmouth Flood Observatory for the development of early warning systems for hydrological hazards [161] and applications of social media for collecting situational information for affected areas in disaster response [162].

\section{Discussion and Conclusions}

We reviewed the geospatial technologies for DRM and discussed their applications. The technologies and applications were developed using the advantages of other complementing technologies for appropriate DRM phases. Interoperability among data sources is an important technical issue when applying geospatial data to DRM, as suggested by the CEOS's reference model. The GEOSS Portal and OGC standards have the important responsibility of promoting the interoperability of geospatial data developed worldwide.

By reviewing the ground-based observation network, it was suggested that communication technology must be considered more in the delivery of geospatial information for DRM, especially in the response phase. The current geospatial technology primarily depends on the Internet and mobile phone networks; however, such systems could be useless if the communications infrastructure is damaged by hazards. Communications satellites and movable communication units are important technologies for establishing resilient systems for DRM. Such communications systems should be included when designing DRM information systems.

In addition, we also reviewed ongoing international activities for DRM. Overall, the activities cover the entire DRM phase from the creation of data and information to the utilization of data and information by the end users and local communities. Therefore, one issue should be how to connect the activities for more efficient operations. Human resources and networks play important roles in connecting activities because the some activities include capacity building programs in disaster-prone areas. In addition, publication of data and information on the Internet will help connect activities so that anyone, even out of the network, can utilize such data and information.

As we reviewed, most of the data providers published their data products on their website in GIS data format. This format will help DRM agencies handle the data for further analysis and the creation of maps using the data on their needs. However, such use of GIS data still requires the efforts of experienced GIS experts which are sometimes not well allocated, especially in emergency response phases. Ready-to-use map formats can help end users access GIS data by allowing them to print out for planning purposes. However, maps should remain browsable at any extent, scale, and time that the end users of the site need.

Although the WebGIS developed by the international efforts that we reviewed satisfies such a need, end users must jump to another WebGIS to browse the GIS data, which are published in a different WebGIS. To reduce such an inefficiency, DisasterAWARE has a notable feature for integrating user-defined datasets in the WebGIS. Data providers are encouraged to publish more GIS data in 
interoperable formats, such as WMS and WFS, as demonstrated by the USGS Emergency Response. This process not only involves technology development but also the arrangement of intellectual properties of the published GIS data. The ODbL is a solution for breaking through the issues, as OSM and third party applications using OSM have demonstrated.

As applications of mobile phones and smart phones are technologically established, more pilots and operations of applications are emerging among international organizations and initiatives. These applications have supported community-based capacity building, which has been demonstrated by UNOSAT and HOT; however, a few pilots and operations remain in the response phases. Furthermore, difficulties remain in applications for disaster emergencies where some basic infrastructure is malfunctioning. Case studies regarding how the technology can support operations during emergencies would help identify possible applications and key technologies that could require more research and development.

A few issues were not considered in this paper. First, administrative issues were not considered. The Hyogo Framework for Action (HFA) suggests that resilience should be strengthened at all level [163], including the national and local authority level. In addition, the post-2015 HFA stated the importance of the role of international cooperation in supporting the efforts of national and local authorities, communities, and businesses [164]. The envisaged framework involves vertical relationships and processes in the national domain and horizontal corporations that are linked through international initiatives [165]. Hence, the envisaged framework should be organized in two dimensions, multi-level and multi-organizational. Therefore, geospatial data delivery schemes should be more comprehensive and indicative of the roles of the national government, local government, local community, and international organizations.

The second issue is the contribution of products at the local level. Although the international initiatives expend significant effort to produce data and maps for DRM, our review did not consider the end users of the data products or how the data were used. Detailed case studies of how these data products were used will be necessary to improve the mechanisms and more effectively deliver data products to people in the field.

\section{Acknowledgments}

This work is supported by the Green Network of Excellence Environmental Information project (GRENE-ei, 2011-2016) of Japan's Ministry of Education, Culture, Sports, Science, and Technology.

\section{Author Contributions}

Hiroyuki Miyazaki had the original idea for structure of the reviews and carried out the reviews of technologies and practices of collaborative data delivery. Masahiko Nagai contributed to the reviews of practices of collaborative data delivery. Ryosuke Shibasaki contributed to the reviews of technologies and practices of collaborative data delivery.

\section{Conflicts of Interest}

The authors declare no conflict of interest. 


\section{References}

1. United Nations International Strategy for Disaster Reduction. Global Assessment Report on Disaster Risk Reduction 2015; United Nations International Strategy for Disaster Reduction: Geneva, Switzerland, 2015; p. 316.

2. Reddick, C. Information technology and emergency management: Preparedness and planning in US states. Disasters 2011, 35, 45-61.

3. Stryker, T.; Jones, B. Disaster response and the international charter program. Photogramm. Eng. Remote Sens. 2009, 75, 1342-1344.

4. Kaku, K.; Held, A. Sentinel Asia: A space-based disaster management support system in the Asia-Pacific region. Int. J. Disaster Risk Reduct. 2013, 6, 1-17.

5. Soden, R.; Palen, L. From crowdsourced mapping to community mapping: The post-earthquake work of OpenStreetMap Haiti. In Proceedings of the 11th International Conference on the Design of Cooperative Systems, COOP 2014, Nice, France, 27-30 May 2014; Rossitto, C., Ciolfi, L., Martin, D., Conein, B., Eds.; Springer International Publishing: Cham, Switzerland, 2014; pp. 311-326.

6. White, B.A.; Rorick, M.M. Cost-Benefit Analysis for Community-Based Disaster Risk Reduction in Kailali, Nepal; Mercy Corps Nepal: Sanepa, Nepal, 2010; p. 23.

7. Venton, C.C.; Venton, P. Disaster Preparedness Programmes in India: A Cost Benefit Analysis; Overseas Development Institute: London, UK, 2004; p. 26.

8. Smith, K. Environmental Hazards: Assessing Risk and Reducing Disaster; Routledge: London, UK, 2013.

9. US National Governors' Association. Comprehensive emergency management: A governor's guide. In Comprehensive Emergency Management: A Governor's Guide; US Defense Civil Preparedness Agency: Washington, DC, USA, 1979.

10. International Risk Governance Council. White Paper on Risk Governance-Towards an Integrative Approach; International Risk Governance Council: Lausanne, Switzerland, 2003.

11. Donahue, A.K.; Joyce, P.G. A framework for analyzing emergency management with an application to federal budgeting. Public Adm. Rev. 2001, 61, 728-740.

12. Evans, J.; Moe, K. GEOSS Architecture for the Use of Remote Sensing Products in Disaster Management and Risk Assessment. Available online: http://ceos.org/document_management/ Working_Groups/WGISS/Projects/GA.4.Disasters/GA.4.Disasters_FINAL-GEOSS-Architecturefor-the-Use-of-Remote-Sensing-Products-in-Disaster-Management-and-Risk-Assessment Dec2013.pdf (accessed on 25 September 2015).

13. Salvi, S.; Stramondo, S.; Funning, G.J.; Ferretti, A.; Sarti, F.; Mouratidis, A. The Sentinel-1 mission for the improvement of the scientific understanding and the operational monitoring of the seismic cycle. Remote Sens. Environ. 2012, 120, 164-174.

14. Lanari, R.; Lundgren, P.; Manzo, M.; Casu, F. Satellite radar interferometry time series analysis of surface deformation for Los Angeles, California. Geophys. Res. Lett. 2004, 31, doi:10.1029/2004GL021294. 
15. Çakir, Z.; Chabalier, J.B.D.; Armijo, R.; Meyer, B.; Barka, A.; Peltzer, G. Coseismic and early post-seismic slip associated with the 1999 Izmit earthquake (Turkey), from SAR interferometry and tectonic field observations. Geophys. J. Int. 2003, 155, 93-110.

16. Hayashi, Y.; Tsushima, H.; Hirata, K.; Kimura, K.; Maeda, K. Tsunami source area of the 2011 off the Pacific coast of Tohoku Earthquake determined from tsunami arrival times at offshore observation stations. Earth Planet Space 2011, 63, 809-813.

17. Lee, K.H.; Wong, M.S.; Chung, S.R.; Sohn, E. Improved volcanic ash detection based on a hybrid reverse absorption technique. Atmos. Res. 2014, 143, 31-42.

18. Pyle, D.M.; Mather, T.A.; Biggs, J. Remote sensing of volcanoes and volcanic processes: Integrating observation and modelling-Introduction. Geol. Soc. Lond. Spec. Publ. 2013, 380, $1-13$.

19. Saavedra Valeriano, O.C.; Koike, T.; Yang, K.; Graf, T.; Li, X.; Wang, L.; Han, X. Decision support for dam release during floods using a distributed biosphere hydrological model driven by quantitative precipitation forecasts. Water Resour. Res. 2010, 46, doi:10.1029/2010WR009502.

20. Shrestha, M.S.; Artan, G.A.; Bajracharya, S.R.; Sharma, R.R. Using satellite-based rainfall estimates for streamflow modelling: Bagmati Basin. J. Flood Risk Manag. 2008, 1, 89-99.

21. Matsueda, M.; Nakazawa, T. Early warning products for severe weather events derived from operational medium-range ensemble forecasts. Meteorol. Appl. 2015, 22, 213-222.

22. Brakenridge, G.R.; Kettner, A.J. Space-based Measurement, Mapping, and Modeling of Surface Water. Available online: http://floodobservatory.colorado.edu/ (accessed on 3 August 2015).

23. Brakenridge, G.R.; Nghiem, S.V.; Anderson, E.; Chien, S. Space-based measurement of river runoff. EOS Trans. Am. Geophys. Union 2005, 86, 185-188.

24. Krishna Bahadur, K.C. Mapping soil erosion susceptibility using remote sensing and GIS: A case of the Upper Nam Wa Watershed, Nan Province, Thailand. Environ. Geol. 2009, 57, 695-705.

25. Prasannakumar, V.; Shiny, R.; Geetha, N.; Vijith, H. Spatial prediction of soil erosion risk by remote sensing, GIS and RUSLE approach: A case study of Siruvani river watershed in Attapady valley, Kerala, India. Environ. Earth Sci. 2011, 64, 965-972.

26. Levin, N.; Heimowitz, A. Mapping spatial and temporal patterns of Mediterranean wildfires from MODIS. Remote Sens. Environ. 2012, 126, 12-26.

27. Sawada, Y.; Koike, T.; Jaranilla-Sanchez, P.A. Modeling hydrologic and ecologic responses using a new eco-hydrological model for identification of droughts. Water Resour. Res. 2014, 50, 6214-6235.

28. Son, N.T.; Chen, C.F.; Chen, C.R.; Chang, L.Y.; Minh, V.Q. Monitoring agricultural drought in the Lower Mekong Basin using MODIS NDVI and land surface temperature data. Int. J. Appl. Earth Observ. Geoinf. 2012, 18, 417-427.

29. Takeuchi, W.; Oyoshi, K.; Muraki, Y. Development of satellite-based drought monitoring and warning system in Asian Pacific countries. In Proceedings of 2013 AGU Fall Meeting, San Francisco, CA, USA, 9-13 December 2013.

30. U.S. Geological Survey; United States Agency for International Development. USGS FEWS NET Data Portal. Available online: http://earlywarning.usgs.gov/fews (accessed on 3 August 2015). 
31. Funk, C.C.; Peterson, P.J.; Landsfeld, M.F.; Pedreros, D.H.; Verdin, J.P.; Rowland, J.D.; Romero, B.E.; Husak, G.J.; Michaelsen, J.C.; Verdin, A.P. A quasi-global precipitation time series for drought monitoring. US Geol. Surv. Data Ser. 2014, 832, doi:10.3133/ds832.

32. Miyazaki, H.; Shao, X.; Iwao, K.; Shibasaki, R. Development of a global built-up area map using ASTER satellite images and existing GIS data. In Global Urban Monitoring and Assessment through Earth Observation; CRC Press: Boca Raton, FL, USA, 2014; pp. 121-142.

33. Esch, T.; Marconcini, M.; Felbier, A.; Roth, A.; Heldens, W.; Huber, M.; Schwinger, M.; Taubenbock, H.; Muller, A.; Dech, S. Urban footprint processor-fully automated processing chain generating settlement masks from global data of the TanDEM-X mission. Geosci. Remote Sens. Lett. 2013, 10, 1617-1621.

34. Bhaduri, B.; Bright, E.; Coleman, P.; Urban, M. LandScan USA: A high-resolution geospatial and temporal modeling approach for population distribution and dynamics. GeoJournal 2007, 69, $103-117$.

35. Wu, J.; Wang, Z.; Li, W.; Peng, J. Exploring factors affecting the relationship between light consumption and GDP based on DMSP/OLS nighttime satellite imagery. Remote Sens. Environ. 2013, 134, 111-119.

36. Shi, K.F.; Yu, B.L.; Huang, Y.X.; Hu, Y.J.; Yin, B.; Chen, Z.Q.; Chen, L.J.; Wu, J.P. Evaluating the ability of NPP-VIIRS nighttime light data to estimate the gross domestic product and the electric power consumption of China at multiple scales: A comparison with DMSP-OLS data. Remote Sens. 2014, 6, 1705-1724.

37. Group on Earth Observations. GEOSS Portal-Discover, Access, Contribute, Earth Observations, Information and Services. Available online: http://www.geoportal.org (accessed on 18 June 2015).

38. Data Integration and Analysis System. A Search and Discovery System for DIAS Datasets. Available online: http://dias-dss.tkl.iis.u-tokyo.ac.jp/ddc/finder?lang=en (accessed on 18 June 2015).

39. Chuvieco, E.; Aguado, I.; Yebra, M.; Nieto, H.; Salas, J.; Martín, M.P.; Vilar, L.; Martínez, J.; Martín, S.; Ibarra, P.; et al. Development of a framework for fire risk assessment using remote sensing and geographic information system technologies. Ecol. Model. 2010, 221, 46-58.

40. Tralli, D.M.; Blom, R.G.; Zlotnicki, V.; Donnellan, A.; Evans, D.L. Satellite remote sensing of earthquake, volcano, flood, landslide and coastal inundation hazards. ISPRS J. Photogramm. Remote Sens. 2005, 59, 185-198.

41. Small, C.; Gornitz, V.; Cohen, J.E. Coastal hazards and the global distribution of human population. Environ. Geosci. 2000, 7, 3-12.

42. Ringrose, S.; Chipanshi, A.C.; Matheson, W.; Chanda, R.; Motoma, L.; Magole, I.; Jellema, A. Climate- and human-induced woody vegetation changes in Botswana and their implications for human adaptation. Environ. Manag. 2002, 30, 98-109.

43. Jackson, R.B.; Randerson, J.T.; Canadell, J.G.; Anderson, R.G.; Avissar, R.; Baldocchi, D.D.; Bonan, G.B.; Caldeira, K.; Diffenbaugh, N.S.; Field, C.B.; et al. Protecting climate with forests. Environ. Res. Lett. 2008, 3, doi:10.1088/1748-9326/3/4/044006.

44. Margono, B.A.; Turubanova, S.; Zhuravleva, I.; Potapov, P.; Tyukavina, A.; Baccini, A.; Goetz, S.; Hansen, M.C. Mapping and monitoring deforestation and forest degradation in Sumatra (Indonesia) using Landsat time series data sets from 1990 to 2010. Environ. Res. Lett. 2012, 7 , doi:10.1088/1748-9326/7/3/034010. 
45. Asian Development Bank. Space Technology and Geographic Information Systems Applications in ADB Projects; Asian Development Bank: Manila, Philippines, 2014; p. 37.

46. Gillespie, T.W.; Chu, J.; Frankenberg, E.; Thomas, D. Assessment and prediction of natural hazards from satellite imagery. Progress Phys. Geogr. 2007, 31, 459-470.

47. Yamaguchi, Y.; Kahle, A.B.; Tsu, H.; Kawakami, T.; Pniel, M. Overview of advanced spaceborne thermal emission and reflection radiometer (ASTER). IEEE Trans. Geosci. Remote Sens. 1998, $36,1062-1071$.

48. Igarashi, T. ALOS mission requirement and sensor specifications. Adv. Space Res. 2001, 28, 127-131.

49. Kankaku, Y.; Suzuki, S.; Osawa, Y. ALOS-2 mission and development status. In Proceedings of the 2013 IEEE International Geoscience and Remote Sensing Symposium (IGARSS), Melbourne, Australia, 21-26 July 2013; pp. 2396-2399.

50. Torres, R.; Snoeij, P.; Geudtner, D.; Bibby, D.; Davidson, M.; Attema, E.; Potin, P.; Rommen, B.; Floury, N.; Brown, M.; et al. GMES Sentinel-1 mission. Remote Sens. Environ. 2012, 120, 9-24.

51. BlackBridge. Satellite Imagery Product Specifications. Available online: http://blackbridge.com/ rapideye/upload/RE_Product_Specifications_ENG.pdf (accessed on 12 September 2015).

52. Covello, F.; Battazza, F.; Coletta, A.; Lopinto, E.; Fiorentino, C.; Pietranera, L.; Valentini, G.; Zoffoli, S. COSMO-SkyMed an existing opportunity for observing the Earth. J. Geodyn. 2010, 49, 171-180.

53. Centre National D'Etudes Spatiales. Pleiades. Available online: http://pleiades.cnes.fr/en/ PLEIADES/index.htm (accessed on 12 September 2015).

54. Aubrecht, C.; Meier, P.; Taubenböck, H. Speeding up the clock in remote sensing: Identifying the "black spots" in exposure dynamics by capitalizing on the full spectrum of joint high spatial and temporal resolution. Nat. Hazards 2015, doi:10.1007/s11069-015-1857-9.

55. Joyce, K.E.; Samsonov, S.V.; Levick, S.R.; Engelbrecht, J.; Belliss, S. Mapping and monitoring geological hazards using optical, LiDAR, and synthetic aperture RADAR image data. Nat. Hazards 2014, 73, 137-163.

56. Voigt, S.; Kemper, T.; Riedlinger, T.; Kiefl, R.; Scholte, K.; Mehl, H. Satellite image analysis for disaster and crisis-management support. IEEE Trans. Geosci. Remote Sens. 2007, 45, 1520-1528.

57. Brown, D.; Saito, K.; Liu, M.; Spence, R.; So, E.; Ramage, M. The use of remotely sensed data and ground survey tools to assess damage and monitor early recovery following the 12.5.2008 Wenchuan earthquake in China. Bull. Earthq. Eng. 2012, 10, 741-764.

58. Wang, S.; So, E.; Smith, P. Detecting tents to estimate the displaced populations for post-disaster relief using high resolution satellite imagery. Int. J. Appl. Earth Observ. Geoinf. 2015, 36, 87-93.

59. US National Oceanic and Atmospheric Administration. Integrated Surface Database. Available online: https://www.ncdc.noaa.gov/isd (accessed on 25 September 2015).

60. US National Oceanic and Atmospheric Administration. Global Surface Summary of the Day. Available online: https:/data.noaa.gov/dataset/global-surface-summary-of-the-day-gsod (accessed on 25 September 2015).

61. Field, R.D.; Wang, Y.; Roswintiarti, O.; Guswanto. A drought-based predictor of recent haze events in western Indonesia. Atmos. Environ. 2004, 38, 1869-1878. 
62. Lee, C.K.; Kim, J.; Kim, K.S. Development and application of a weather data service client for preparation of weather input files to a crop model. Comput. Electron. Agric. 2015, 114, 237-246.

63. Doesken, N.; Reges, H. The value of the citizen weather observer. Weatherwise 2010, 63, 30-37.

64. The Weather Channel. Weather Underground. Available online: http://www.wunderground.com/ (accessed on 18 June 2015).

65. Muller, C.L.; Chapman, L.; Johnston, S.; Kidd, C.; Illingworth, S.; Foody, G.; Overeem, A.; Leigh, R.R. Crowdsourcing for climate and atmospheric sciences: Current status and future potential. Int. J. Climatol. 2015, 35, 3185-3203.

66. Banerjee, P.; Pollitz, F.F.; Burgmann, R. The size and duration of the Sumatra-Andaman earthquake from far-field static offsets. Science 2005, 308, 1769-1772.

67. Ohta, Y.; Meilano, I.; Sagiya, T.; Kimata, F.; Hirahara, K. Large surface wave of the 2004 Sumatra-Andaman earthquake captured by the very long baseline kinematic analysis of 1-Hz GPS data. Earth Planet Space 2006, 58, 153-157.

68. Shi, C.; Lou, Y.; Zhang, H.; Zhao, Q.; Geng, J.; Wang, R.; Fang, R.; Liu, J. Seismic deformation of the Mw 8.0 Wenchuan earthquake from high-rate GPS observations. Adv. Space Res. 2010, 46, $228-235$.

69. National Geodetic Survey. Continuously Operating Reference Station (CORS). Available online: http://geodesy.noaa.gov/CORS/ (accessed on 19 June 2015).

70. International GNSS Service. Available online: http://igs.org/ (accessed on 19 June 2015).

71. Kato, T.; Terada, Y.; Nishimura, H.; Nagai, T.; Koshimura, S.I. Tsunami records due to the 2010 Chile Earthquake observed by GPS buoys established along the Pacific coast of Japan. Earth Planet Space 2011, 63, e5-e8.

72. Wei, Y.; Newman, A.; Hayes, G.; Titov, V.; Tang, L. Tsunami forecast by joint inversion of real-time tsunami waveforms and seismic or GPS data: Application to the Tohoku 2011 tsunami. Pure Appl. Geophys. 2014, 171, 3281-3305.

73. Kato, T.; Terada, Y.; Ito, K.; Hattori, R.; Abe, T.; Miyake, T.; Koshimura, S.I.; Nagai, T. Tsunami due to the 2004 September 5 th off the Kii peninsula earthquake, Japan, recorded by a new GPS buoy. Earth Planet Space 2005, 57, 297-301.

74. Nemoto, Y.; Hamaguchi, K. Resilient ICT research based on lessons learned from the Great East Japan Earthquake. IEEE Commun. Mag. 2014, 52, 38-43.

75. Sakano, T.; Fadlullah, Z.M.; Thuan, N.; Nishiyama, H.; Nakazawa, M.; Adachi, F.; Kato, N.; Takahara, A.; Kumagai, T.; Kasahara, H.; et al. Disaster-resilient networking: A new vision based on movable and deployable resource units. IEEE Trans. Commun. 2013, 27, 40-46.

76. Allahbakhsh, M. Quality Control in crowdsourcing systems: Issues and directions. IEEE Internet Comput. 2013, 17, 76-81.

77. Heipke, C. Crowdsourcing geospatial data. ISPRS J. Photogramm. Remote Sens. 2010, 65, 550-557.

78. Ushahidi. Available online: http://www.ushahidi.com/ (accessed on 18 June 2015),

79. Sahana Software Foundation. Available online: http://sahanafoundation.org/ (accessed on 18 June 2015). 
80. Gao, H.; Barbier, G.; Goolsby, R. Harnessing the crowdsourcing power of social media for disaster relief. IEEE Intell. Syst. 2011, 26, 10-14.

81. Dugdale, J.; Walle, B.V.D.; Koeppinghoff, C. Social media and SMS in the Haiti earthquake. In Proceedings of the 21st International Conference Companion on World Wide Web, Lyon, France, 16-20 April 2012; pp. 713-714.

82. Neis, P.; Zielstra, D. Recent developments and future trends in volunteered geographic information research: The case of OpenStreetMap. Future Internet 2014, 6, 76-106.

83. Open Knowledge Foundation. Open Data Commons Open Database License (ODbL). Available online: http://opendatacommons.org/licenses/odbl/ (accessed on 18 June 2015).

84. Junhua, L.; Moore, N.; Akter, S.; Bleisten, S.; Ray, P. mHealth for influenza pandemic surveillance in developing countries. In Proceedings of the 43rd Hawaii International Conference on System Sciences (HICSS), Honolulu, HI, USA, 5-8 January 2010; pp. 1-9.

85. Mahmud, N.; Rodriguez, J.; Nesbit, J. A text message-based intervention to bridge the healthcare communication gap in the rural developing world. Technol. Health Care 2010, 18, 137-144.

86. FrontlineSMS; Ushahidi. How to set-up Ushahidi and FrontlineSMS for use together. Available online: http://www.frontlinesms.com/wp-content/uploads/2012/03/FrontlineSMS-Ushahidi_StepBy-Step-Guide_Final.pdf (accessed on 17 June 2015).

87. Google. Our Mobile Planet. Available online: https://think.withgoogle.com/mobileplanet (accessed on 18 June 2015).

88. Open Geospatial Consortium. Open GeoSMS Standard-Core. Available online: https://portal.opengeospatial.org/files/?artifact_id=44146 (accessed on 25 September 2015).

89. Meier, P.; Munro, R. The unprecedented role of SMS in disaster response: Learning from Haiti. SAIS Rev. Int. Aff. 2010, 30, 91-103.

90. Rahman, K.M.; Alam, T.; Chowdhury, M. Location based early disaster warning and evacuation system on mobile phones using OpenStreetMap. In Proceedings of 2012 IEEE Conference on Open Systems (ICOS), Kuala Lumpur, Malaysia, 21-24 October 2012; pp. 1-6.

91. Levental, S. A new geospatial services framework: How disaster preparedness efforts should integrate neogeography. J. Map Geogr. Libr. 2012, 8, 134-162.

92. Chen, K.; McAneney, J. High-resolution estimates of Australia's coastal population. Geophys. Res. Lett. 2006, 33, doi:10.1029/2006GL026981.

93. Tatem, A.J.; Campiz, N.; Gething, P.W.; Snow, R.W.; Linard, C. The effects of spatial population dataset choice on estimates of population at risk of disease. Popul. Health Metr. 2011, 9, doi:10.1186/1478-7954-9-4.

94. Center for International Earth Science Information Network (CIESIN); Columbia University; Centro Internacional de Agricultura Tropical (CIAT). Gridded Population of the World, Version 3 (GPWv3): Population Density Grid; NASA Socioeconomic Data and Applications Center: Palisades, NY, USA, 2005. Available online: http://dx.doi.org/10.7927/H4XK8CG2 (accessed 25 September 2015).

95. Dobson, J.E.; Bright, E.A.; Coleman, P.R.; Durfee, R.C.; Worley, B.A. LandScan: A global population database for estimating populations at risk. Photogramm. Eng. Remote Sens. 2000, 66, 849-857. 
96. Sorichetta, A.; Hornby, G.M.; Stevens, F.R.; Gaughan, A.E.; Linard, C.; Tatem, A.J. High-resolution gridded population datasets for Latin America and the Caribbean in 2010, 2015, and 2020. Sci. Data 2015, 2, doi:10.1038/sdata.2015.45.

97. Freire, S.; Aubrecht, C. Integrating population dynamics into mapping human exposure to seismic hazard. Nat. Hazard. Earth Syst. Sci. 2012, 12, 3533-3543.

98. Aubrecht, C.; Steinnocher, K.; Huber, H. DynaPop-Population distribution dynamics as basis for social impact evaluation in crisis management. In Proceedings of the 11th International ISCRAM Conference, University Park, PA, USA, 18-21 May 2014.

99. Martin, D.; Cockings, S.; Leung, S. Developing a flexible framework for spatiotemporal population modeling. Ann. Assoc. Am. Geogr. 2015, 105, 754-772.

100. Song, X.; Zhang, Q.S.; Sekimoto, Y.; Horanont, T.; Ueyama, S.; Shibasaki, R. Intelligent system for human behavior analysis and reasoning following large-scale disasters. IEEE Intell. Syst. 2013, $28,35-42$.

101. Wesolowski, A.; Eagle, N.; Tatem, A.J.; Smith, D.L.; Noor, A.M.; Snow, R.W.; Buckee, C.O. Quantifying the impact of human mobility on Malaria. Science 2012, 338, 267-270.

102. Pastor-Escuredo, D.; Morales-Guzman, A.; Torres-Fernandez, Y.; Bauer, J.M.; Wadhwa, A.; Castro-Correa, C.; Romanoff, L.; Jong Gun, L.; Rutherford, A.; Frias-Martinez, V.; et al. Flooding through the lens of mobile phone activity. In Proceedings of the 2014 IEEE Global Humanitarian Technology Conference (GHTC), San Jose, CA, USA, 10-13 October 2014; pp. 279-286.

103. Chen, F.; Zhai, Z.; Madey, G. Dynamic adaptive disaster simulation: Developing a predictive model of emergency behavior using cell phone and GIS data. In Proceedings of the 2011 Workshop on Agent-Directed Simulation, Society for Computer Simulation International, Boston, MA, USA, 3-7 April 2011; pp. 5-12.

104. Talbot, D. Cell-Phone Data Might Help Predict Ebola's Spread. Available online: http://www. technologyreview.com/news/530296/cell-phone-data-might-help-predict-ebolas-spread/ (accessed on 17 June 2015).

105. Bengtsson, L.; Lu, X.; Thorson, A.; Garfield, R.; von Schreeb, J. Improved response to disasters and outbreaks by tracking population movements with mobile phone network data: A post-earthquake geospatial study in Haiti. Plos Med. 2011, 8, doi:10.1371/journal.pmed.1001083.

106. Perusco, L.; Michael, K. Control, trust, privacy, and security: Evaluating location-based services. IEEE Technol. Soc. Mag. 2007, 26, 4-16.

107. Iqbal, M.U.; Samsung, L. Privacy Implications of automated GPS tracking and profiling. IEEE Technol. Soc. Mag. 2010, 29, 39-46.

108. Gasson, M.N.; Kosta, E.; Royer, D.; Meints, M.; Warwick, K. Normality mining: Privacy implications of behavioral profiles drawn from GPS enabled mobile phones. IEEE Trans. Syst. Man Cybern. Part C Appl. Rev. 2011, 41, 251-261.

109. Ghinita, G. Private queries and trajectory anonymization: A dual perspective on location privacy. Trans. Data Priv. 2009, 2, 3-19.

110. Chen, K.; Blong, R.; Jacobson, C. MCE-RISK: Integrating multicriteria evaluation and GIS for risk decision-making in natural hazards. Environ. Model. Softw. 2001, 16, 387-397. 
111. Al-Khudhairy, D.H.A. Geo-spatial information and technologies in support of EU crisis management. Int. J. Digit. Earth 2010, 3, 16-30.

112. Open Geospatial Consortium. OpenGIS Web Map Service (WMS) Implementation Specification. Available online: http://portal.opengeospatial.org/files/?artifact_id=14416 (accessed on 17 June 2015).

113. Open Geospatial Consortium. OpenGIS Web Feature Service 2.0 Interface Standard. Available online: http://portal.opengeospatial.org/files/?artifact_id=39967 (accessed on 17 June 2015).

114. Sayar, A.; Pierce, M.; Fox, G. OGC Compatible Geographical Information Systems Web Services; Indiana University: Bloomington, IN, USA, 2005.

115. National Aeronautics and Space Administration (NASA). Global Imagery Browse Services-GIBS. Available online: https://wiki.earthdata.nasa.gov/display/GIBS/ (accessed on 17 June 2015).

116. Center for International Earth Science Information Network (CIESIN). List of Map Services. Available online: http://beta.sedac.ciesin.columbia.edu/maps/services (accessed on 17 June 2015).

117. Oak Ridge National Laboratory. Spatial Data Access Tool (SDAT). Available online: http://webmap.ornl.gov/wcsdown/ (accessed on 17 June 2015).

118. Karnatak, H.C.; Shukla, R.; Sharma, V.K.; Murthy, Y.V.S.; Bhanumurthy, V. Spatial mashup technology and real time data integration in geo-web application using open source GIS-A case study for disaster management. Geocarto Int. 2012, 27, 499-514.

119. Center for International Earth Science Information Network. SEDAC Hazards Mapper. Available online: http://sedac.ciesin.columbia.edu/mapping/hazards/ (accessed on 3 August 2015).

120. Pacific Disaster Center. PDC DisasterAWARE. Available online: http://atlas.pdc.org/atlas/ (accessed on 3 August 2015).

121. Jones, C.E.; Haklay, M.; Griffiths, S.; Vaughan, L. A less-is-more approach to geovisualization-enhancing knowledge construction across multidisciplinary teams. Int. J. Geogr. Inf. Sci. 2009, 23, 1077-1093.

122. Ikeda, S.; Sato, T.; Fukuzono, T. Towards an integrated management framework for emerging disaster risks in Japan. Nat. Hazard. 2008, 44, 267-280.

123. Merrett, H.C.; Chen, W.W. Applications of geographical information systems and remote sensing in natural disaster hazard assessment and mitigation in Taiwan. Geomat. Natl. Hazard. Risk 2012, 4, 145-163.

124. Ikeda, S.; Nagasaka, T. An emergent framework of disaster risk governance towards innovating coping capability for reducing disaster risks in local communities. Int. J. Disaster Risk Sci. 2011, $2,1-9$.

125. The Economist. Halfway There: How to Promote the Spread of Mobile Phones among the World'S Poores; The Economist: London, UK, 2008.

126. InSTEDD. Verboice. Available online: http://instedd.org/technologies/verboice/ (accessed on 18 June 2015),

127. InSTEDD. Reporting Wheel. Available online: http://instedd.org/technologies/reporting-wheel/ (accessed on 18 June 2015).

128. United Nations Office for Disaster Risk Reduction. Available online: http://www.unisdr.org/ (accessed on 18 August 2015). 
129. United Nations Office for Outer Space Affairs. UN-SPIDER Knowledge Portal. Available online: http://www.un-spider.org/ (accessed on 18 August 2015).

130. AHA Centre. Available online: http://www.ahacentre.org/ (accessed on 18 August 2015).

131. Asian Disaster Preparedness Center. Available online: http://www.adpc.net/ (accessed on 18 August 2015).

132. Asian Disaster Reduction Center. Available online: http://www.adrc.asia/ (accessed on 18 August 2015).

133. Ghosh, S.; Huyck, C.K.; Greene, M.; Gill, S.P.; Bevington, J.; Svekla, W.; DesRoches, R.; Eguchi, R.T. Crowdsourcing for rapid damage assessment: The global earth observation catastrophe assessment network (GEO-CAN). Earthq. Spectra. 2011, 27, S179-S198.

134. Skinnemoen, H. ASIGN-Mission-critical visual communications for integrated space applications. In Proceedings of the 2014 IEEE International Conference on Aerospace Electronics and Remote Sensing Technology (ICARES), Yogyakarta, Indonesia, 13-14 November 2014; pp. 107-113.

135. Japan Aerospace Exploration Agency. Sentinel Asia. Available online: http://sentinel.tksc.jaxa.jp/ (accessed on 18 August 2015).

136. International Charter. International Disasters Charter. Available online: http://www. disasterscharter.org/ (accessed on 18 August 2015).

137. UNITAR's Operational Satellite Applications Programme. Available online: http://www.unitar.org/ unosat/ (accessed on 22 June 2015).

138. United Nations institute for Training and Research. IGAD Introduction to GIS for Disaster Risk Reduction. Available online: https://www.unitar.org/event/igad-introduction-gis-disaster-riskreduction (accessed on 19 June 2015).

139. United Nations Institute for Training and Research. Introduction to GIS \& RS Applications for the IGAD Drought Disaster Resilience and Sustainability Initiative (IDDRSI). Available online: https://www.unitar.org/event/introduction-gis-rs-applications-igad-drought-disaster-resilience-andsustainability-initiative-iddr (accessed on 19 June 2015).

140. European Union. Copernicus Emergency Management Service-Mapping. Available online: http://emergency.copernicus.eu/ (accessed on 13 August 2015).

141. Saunier, S.; Camlong, N.; Floissac, P.; Hillairet, E.; Berthelot, B.; Gorman, M.; Ottavianelli, G.; Amans, V. Coordinating and monitoring quality information for the copernicus services: Case study with optical data abstractuFFFD. IEEE Geosci. Remote Sens. Mag. 2015, 3, 24-40.

142. Grandoni, D.; Battagliere, M.L.; Daraio, M.G.; Sacco, P.; Coletta, A.; Di Federico, A.; Mastracci, F. Space-based technology for emergency management: The COSMO-SkyMed constellation contribution. Procedia Technol. 2014, 16, 858-866.

143. European Commision Joint Research Centre. European Flood Awareness System (EFAS). Available online: http://www.efas.eu/ (accessed on 13 August 2015).

144. U.S. Geological Survey. Emergency Operations Portal. Available online: http://hdds.usgs.gov/ (accessed on 13 August 2015).

145. Humanitarian OpenStreetMap Team. Available online: http://hotosm.org/ (accessed on 18 August 2015). 
146. OpenStreetMap Foundation. Humanitarian OSM Team. Available online: http://wiki.openstreetmap. org/wiki/Humanitarian_OSM_Team (accessed on 17 June 2015).

147. Chan, J.L.; Colombo, R.; Musani, A. Mapping libyan health facilities-A collaboration between crisis mappers and the world health organization. In Proceedings of the 9th International ISCRAM Conference, Vancouver, BC, Canada, 22-25 April 2012.

148. Soden, R. 4 Years on, Looking Back at OpenStreetMap Response to the Haiti Earthquake. Available online: http://blogs.worldbank.org/latinamerica/4-years-looking-back-openstreetmapresponse-haiti-earthquake (accessed on 19 June 2015).

149. Humanitarian OpenStreetMap Team. Indonesia. Available online: http://hotosm.org/projects/ indonesia-0 (accessed on 19 June 2015).

150. National Aeronautics and Space Administration; United States Agency for International Development; Regional Centre for Mapping of Resources for Development; International Centre for Integrated Mountain Development; Asian Disaster Preparedness Center. SERVIR GLOBAL. Available online: http://www.servirglobal.net/ (accessed on 18 August 2015).

151. National Aeronautics and Space Administration; United States Agency for International Development. ISERV. Available online: https://www.servirglobal.net/Data-Maps/ISERV (accessed on 10 August 2015).

152. Stefanov, W.; Evans, C. Data collection for disaster response from the international space station. In Proceedings of the 36th International Symposium on Remote Sensing of Environment, Berlin, Germany, 11-15 May 2015.

153. United States Agency for International Development. Famine Early Warning Systems Network. Available online: http://www.fews.net/ (accessed on 18 August 2015).

154. Funk, C.C.; Brown, M.E. Intra-seasonal NDVI change projections in semi-arid Africa. Remote Sens. Environ. 2006, 101, 249-256.

155. Brown, M.E.; de Beurs, K.M. Evaluation of multi-sensor semi-arid crop season parameters based on NDVI and rainfall. Remote Sens. Environ. 2008, 112, 2261-2271.

156. Laben, C. Integration of remote sensing data and geographic information system technology for emergency managers and their applications at the Pacific Disaster Center. OPTICE 2002, 41, 2129-2136.

157. Pacific Disaster Center. Pacific Disaster Center. Available online: http://www.pdc.org/ (accessed on 18 August 2015).

158. Group on Earth Observations. Geohazard Supersites and Natural Laboratories (GSNL). Available online: http://www.earthobservations.org/gsnl.php (accessed on 18 August 2015).

159. Plag, H.P.; Amelung, F.; Lengert, W.; Marsh, S.H.; Meertens, C. Supporting risk management and disaster reduction: The geohazards community of practice and the supersite initiative. In Proceedings of the ISPRS Technical Commission VIII Symposium, Kyoto, Japan, 9-12 August 2010; pp. 193-198.

160. European Commission. Global Disaster Alert and Coordination System. http://www.gdacs.org/ (accessed on 18 August 2015).

161. European Commission Joint Research Centre. Global Flood Detection System-Version 2. Available online: http://www.gdacs.org/flooddetection/ (accessed on 13 August 2015). 
162. Stollberg, B.; De Groeve, T. The use of social media within the global disaster alert and coordination system (GDACS). In Proceedings of the 21 st International World Wide Web Conference, Lyon, France, 16-20 April 2012; pp. 703-706.

163. International Strategy for Disaster Reduction. Hyogo framework for action 2005-2015: Building the resilience of nations and communities to disasters. In Proceedings of the World Conference on Disaster Reduction (A/CONF. 206/6), Hyogo, Japan, 18-22 January 2005.

164. United Nations. Sendai Framework for Disaster Risk Reduction 2015-2030; United Nations: New York, NY, USA, 2015.

165. Maldonado, E.; Maitland, C.; Tapia, A. Collaborative systems development in disaster relief: The impact of multi-level governance. Inf. Syst. Front. 2010, 12, 9-27.

(C) 2015 by the authors; licensee MDPI, Basel, Switzerland. This article is an open access article distributed under the terms and conditions of the Creative Commons Attribution license (http://creativecommons.org/licenses/by/4.0/). 